\title{
KNUT WICKSELL AND LUDWIG VON MISES ON MONEY, INTEREST AND PRICE DYNAMICS
}

\author{
BY
}

\section{AGNÈS FESTRÉ*}

\begin{abstract}
The purpose of the paper is to compare Wicksell's and von Mises' theories of money, interest and price dynamics in the light of the debate that took place between them two years after the publication of Mises' Theory of Money and Credit (1912). This debate revealed two main issues that divided the two authors: on the one hand, Wicksell and Mises do not agree on the relation between the 'money market' and the 'commodity market'; on the other hand, they do not share the same view as regards the question of the dependence (or interdependence) of the 'loan rate of interest' from the 'natural rate of interest'. We shall discuss those two related questions in the first section. Then, in the second section, we shall analyze how these divergences affected Wicksell’s and Mises’ respective theories of economic dynamics.
\end{abstract}

\footnotetext{
* The author belongs to the G.R.E.D.E.G. - D.E.M.O.S. - C.N.R.S. / University of Nice - Sophia Antipolis, 250 rue Albert Einstein, 06560 VALBONNE CEDEX, FRANCE, festre@idefi.cnrs.fr.
} 


\section{INTRODUCTION}

In the aftermath of the so-called 'Marginal Revolution' of the last end of the XIX ${ }^{\text {th }}$, economic analysis split into two branches. The first one was made up of economists who took as the methodological starting-point of their analyses the static or stationary state of a barter economy and considered that this basic framework was likely to be extended in order to account for monetary and financial considerations as well as dynamics. However, in such a setting, the introduction of money, bank-credit or any factor of growth did not substantially alter the features that are associated with the rudimentary economy of static real exchange. This tradition is to be distinguished from a second one, which one can trace back to Wicksell. According to this second tradition, and in contrast to the orthodox monetary view, the introduction of the organization of bank credit in the field of economic theory implied substantial changes as regards economic analysis. In particular, the ex novo and endogenous nature of credit-money modifies the conditions under which the mechanisms of co-ordination between savings and investment operate. More precisely, while in a barter economy these two magnitudes are defined in real terms, in a monetary one, credit money may to a certain extent become a substitute for real savings. Thus, by altering co-ordination between savings and investment, the organization of the banking system may allow the emergence of global disequilibria.

Historically, Wicksell has the first to deal in analytical terms with this issue by introducing the well-known distinction between the money rate of interest and the natural (or normal) rate of interest. Mises, in his Theory of Money and Credit (TMC) first published in 1912, resorts to a similar distinction. 
Nevertheless, though starting from the same distinction, Wicksell and Mises developed rather distinct analyses of price movement dynamics. While Wicksell focused on price level fluctuations, Mises built a theoretical framework in which business cycles are due to shifts in relative prices.

In a first section, we shall discuss the main issues that divided Wicksell and Mises in 1914: We will first analyze how the two authors conceived the link between the 'commodity market' and the 'money market' as well as their respective stance on the question of the independence of the 'loan rate of interest' from the 'natural rate of interest'. Then, in a second section, we shall analyze how those differences did affect Wicksell and Mises' theories of economic dynamics.

\section{THE MAIN ISSUES OF THE DEBATE}

As already emphasized, the divergences between the theories of Mises and Wicksell are related to two major issues that divided them during a debate that took place after the publication of Mises' Theorie des Geldes und der Umlaufsmittel (Theory of Money and Credit) in 1912. In this book, Mises builds his own monetary theory of the cycle ${ }^{1}$ on the basis of a critical reconstruction of Wicksell's analysis on the relation between the rate of interest on loans and the natural rate of interest. Wicksell answers to the critique in 1914 by publishing a review of Mises’s 1912 book in the Zeitschrift für Volkswirtschaft, Sozialpolitik und Verwaltung ${ }^{2}$.

Surprisingly enough, in subsequent editions of his Theory of Money and Credit (TMC) Mises never replied to Wicksell's review and never modified any of the objections to Wicksell. Moreover, even to-day, few commentators refer to this debate ${ }^{3}$. 
The two major issues raised by Wicksell's review relates to the question of the relation between the 'commodity market' and the 'money market' on the one hand, and to the dynamics between the 'loan rate of interest' and the 'natural rate of interest', on the other hand. Although both authors varied on the definition of the 'natural' or real rate of interest, the bone of contention concerned the dynamics between the two rates. While Mises insisted on the interdependence of both rates, Wicksell always regarded the mutual effect on one another as non existent or, at the most, as a "secondary factor"4 (for a discussion of how Wicksell revised his monetary theory, see the introduction by Ohlin to the second edition of Interest and Prices, p. xvii).

One of the aims of this section is to clarify the debate between both authors by elaborating on the issues at stake in Mises' criticisms of Wicksell monetary theory as found in his TMC as well as in Wicksell's reply to those criticisms in his 1914 Review.

\section{1. The methodological question of the interdependence of the 'commodity market' and the 'money market'}

Wicksell's contribution to monetary theory is a set of heterogeneous writings, which gives the reader the impression that he was always revising his theory of money. These writings are mainly found in Interest and Prices (1898), in the second volume of his Lectures of Political Economy (1906) and in a 1907 article entitled: “The influence of the rate of interest on prices”, published in the Economic Journal. Moreover, Wicksell published a number of important papers on monetary theory in the Ekonomisk Tidskrift that have unfortunately not been translated in English ${ }^{5}$. 
The usual interpretation of Wicksell in this field theory consists in presenting the author as an ordinary quantity theorist (see, for instance, Patinkin 1965), although Wicksell's attitude towards the quantity theory of money was ambiguous. In fact, Wicksell's was dissatisfied with the Quantity Theory, in particular, because it was contradictory not to account for the fact, as pointed out by Tooke and Newmarch (18381856), that the rate of interest had on the whole been low during times of falling prices and high during times of rising prices. Although Wicksell considered the work of Tooke and Newmarch to be non-theoretic, he was convinced that the two perspectives, the Quantity Theory apparatus on one hand, and the empirical evidence on the other, could be reconciled.

More precisely, Wicksell's dissatisfaction with the quantity theory relates to two issues. First, he indicated that, in order for this theory to be valid, a constant velocity of money has to be assumed 'Wicksell [1936] 1965: 42).

The second issue concerns the transmission mechanism between money and prices that is implied by the quantity theory:

\footnotetext{
"That a large and a small quantity of money can serve the same purposes of turnover if commodity prices rise or fall proportionately to the quantity is one thing. It is another thing to show why such a change of price must always follow a change in the quantity of money and to describe it.” (Wicksell [1936] 1965: 160)
}

Wicksell is indeed aware of the limit of defining the relation between money and goods in the terms of one another ${ }^{6}$. This is possible only if money serves as a medium of exchange in instantaneous transactions. As soon as one allows for money as a reserve of value or for credit transactions, forces operating on the two markets are not separated any longer from one 
another. This leads Wicksell to break with the classical dichotomy as well as reject Say's law as an identity (Wicksell [1935] 1967, p. 159):

In order to specify the relation between the commodity market and the money market, Wicksell compares different (fictitious) stages of development of the organization of credit within an economic system. He distinguishes between two imaginary polar cases: the 'pure cash economy', where the velocity of circulation of money is constant and where there is no lending of money nor credit and where the classical dichotomy applies (Wicksell [1936] 1965, pp. 51-59); the 'organized credit economy' or 'pure credit' economy, where the three former principles are ruled out (Ibid pp. 62-80).

In a pure credit economy, the supply of money consists only of current accounts and bank notes, i.e. purely endogenous money. The velocity of money encounters no limits and the classical mechanism of supply and demand does not apply anymore:

\footnotetext{
"The various practical obstacles which stand in the way of ideally perfect mobility of money are gradually being removed as a result of concentration in the hands of the banks of cash holdings and of the business of lending, and of the use of bills and notes, cheques and clearing methods. Money is continually becoming more fluid, and the supply of money is more and more inclined to accommodate itself to the level of demand.” (Wicksell [1936] 1965: 110)
}

In such a system, price stability cannot result from the mechanical operation of the real balance effect. Wicksell's explanation is that a certain level of the interest rate, called the “normal” rate of interest is the only one consistent with price stability.

Let us now turn to Mises’ viewpoint concerning the relation between the money and the commodity market. 
As we already emphasized, Mises is one of the Austrian economists who, along with Menger, contributed most to the development of the Austrian theory of money. In his Theory of Money and Credit (TMC), Mises’ endeavoured to integrate monetary analysis within Austrian theory of value, so that the two becomes the same. According to him, the main task of monetary theory was to determine the 'objective exchange value of money', i.e., in fact, its purchasing power: “by 'the objective exchange value of money’ we accordingly to should understand the possibility of obtaining a certain quantity of other economic goods in exchange for a given quantity of money.” (Mises [1924] 1981, p. 122). It should be pointed out that Mises' notion of 'objective exchange value of money', as he himself made clear, "has nothing to do except its name in common with the old idea developed by the Classical School of a value in exchange inherent in things themselves.” (Ibid. p. 121). On the contrary, Mises’ conception of money directly springs from his subjectivist approach. First, as he puts it, the essential function of money is to facilitate the interexchange of goods and services. The other functions of money, as a means of payment or as a reserve of value, are therefore merely derived functions from the former (Ibid. pp. 46-47). Second, Mises considers that it is necessary to have a theory of the objective exchange value of money if one wants to build a subjective theory of the value of money. He indeed defines the price of money, like any other price, as "determined in the last resort by the subjective valuations of buyers and sellers." (Mises [1924] 1981, p. 120). This means that the subjective exchange value of money is nothing but the anticipated use-value of the things that are to be bought with it ${ }^{7}$. Such a conception of money conflicts with the prevailing contemporary quantity theory of money. On one hand, Mises regards the quantity theory as unsatisfactory, because it fails to account for the connection between the quantity of money and subjective evaluations of relative prices: 
“(...) the only valid objection to [the quantity theory] is that it does not go back to the ultimate determinants of prices. It is correct or incorrect, according to the content given to the words demand and supply. It is correct, if account is taken of all the factors that motivate people in buying and selling. It is incorrect, if supply and demand are interpreted and compared in a merely quantitative sense.” (Mises [1924] 1981: 151)

On the other hand, Mises, considers, as Wicksell but for dissimilar theoretical reasons, that the practical relevance of the quantity theory is invalidated by the development of credit, and hence, is of no help for monetary policy:

\footnotetext{
'It is said that the fluctuating velocity of circulation of money, and the elasticity of methods of payment made possible by the credit system and the progressive improvement of banking organization and technique (...) have made the movement of prices as far as is possible independent of variations in the quantity of money(...).' (Mises [1924] 1981: 173)
}

Building on Menger, Mises indeed developed an elaborate theory of money and credit that is perhaps best characterised by a term that Hayek later used, i.e. by an "inverted pyramid” (Hayek 1935, p. 99). Beginning with commodity money, Mises then shows how banks can substitute claims to commodities (e.g., gold certificates), i.e., what he calls 'money substitutes’, for the commodities themselves (Mises [1924] 1981, p. 50). Then, since banks provide what he calls 'circulation credit' through their savings-deposit-lending activities (Mises [1924] 1981, p. 270), they can create a new kind of money based on credit, which he calls ‘credit money’, or ‘fiduciary media’ (Mises [1924] 1981, p. 61 \& p. 268). Fiduciary media are money based on circulating credit and constitute real substitutes for money ${ }^{8}$. Now, regarding the connection between the money market and the commodity market, Mises criticizes Wicksell's perspective. In his TMC, he points out that: 
“According to [Wicksell's] argument, the objective exchange value of money is not determined at all by the processes of the market in which money and the other economic goods are exchanged. If the money price of a single commodity or group of commodities is wrongly assessed in the market, then the resulting maladjustment of the supply and demand and the production and consumption of this commodity or group of commodities will sooner or later bring about the necessary correction. If, on the other hand, all commodity prices, or the average price level, should for any reason be raised or lowered, there is no factor in the circumstances of the commodity market that could bring about a reaction. Consequently, if there is to be any reaction at all against a price assessment that is either too high or too low it must in some way or other originate outside the commodity market. In the further course of his argument, Wicksell arrives at the conclusion that the regulator of money prices is to be sought in the relations of the commodity market to the money market, in the broadest sense of the term. The cause which influences the demand for raw materials, labor and other means of production, and thus indirectly determines the upward or downward movement of commodity prices, is the ratio between the money rate of interest (...) and the "natural” or equilibrium rate of interest (...). In fact, all that [Wicksell] attempts to prove is that forces operate from the loan market on the commodity market which prevent the objective exchange value of money from rising too high or falling too low. He never asserts that the rate of interest on loans determines the actual level of this value in any way (...).” (Mises [1924] 1981: 140).

By this statement, we are to understand that, in contrast to Wicksell, Mises provides a theory of the determination of the 'rate of interest on loans', which is not to be considered as different in natura from the one that determines the ratio between money and other economic goods. In his framework, the interest on loans or the monetary rate of interest is indeed identical to 'the interest on capital' since, as rightly pointed out by Bellofiore, there is neither fixed capital nor explicit account of a bond market in Mises’ analysis. Therefore, the capital market is included, and confused with the money market (Bellofiore 1998, p. 542). From here, and following Böhm-Bawerk’s theory of interest ${ }^{9}$, Mises considers that the variations in the ratio of exchange between present goods and goods of higher orders ${ }^{10}$, from which the 
natural phenomenon of interest is derived, 'are not different phenomena from the variations in the objective exchange value of money' (Mises [1924] 1981, p. 388). The phenomenon of interest is thus derived from the variations in the ratio of exchange between present and future goods. Under these circumstances, any modification in the supply of fiduciary media is translated into a change in the rate of interest. Therefore, Mises' analysis of the connection between variations in the objective exchange value of money and variations in the rate of interest is to be interpreted in the following manner. With given demand, an increase of the supply of money in the broader sense brings out excess cash balances, which implies a market pressure towards higher goods’ prices. But money does not flow into the economic circuit uniformly and instantaneously. It goes in the first place towards intermediate goods, so that the prices of production goods rise more than consumption goods ${ }^{11}$. Hence, the rise in the price of consumption goods, i.e., the fall in the objective exchange value of money, is at first all of a piece with the rise in the relative price of production goods over consumption goods, i.e., a decrease in the rate of interest. (Mises [1924] 1981, p. 388).

At first sight, the problem Mises raises - namely, the problem of the determination of the 'objective exchange value of money'- comes to the same thing as the determination of the ‘absolute level of money prices’ in Wicksell's analysis. However, the two authors do not agree concerning the connection between the money market and the commodity market. Wicksell considers that the two markets are independent, as rightly emphasized by Mises in his TMC, in the following quotation of Wicksell' Interest and Prices:

"[T]he laws of the exchange of commodities contain in themselves nothing that could determine the absolute level of money prices.” (Wicksell [1936] 1965: 35; quoted by Mises [1924] 1981: 141) 
Mises, on the other hand, makes clear that the market for commodities is connected to the market for money:

"If the circumstances of the loan market [i.e. the money market] can provide no explanation of the genesis of the exchange ratio subsisting between money and other economic goods, then neither can they help to explain why this ratio does not alter. The objective exchange value of money is determined in the market where money is exchanged for commodities and commodities for money. To explain this determination is the task of the theory of money.” (Mises [1924] 1981:

However, in such a framework, the 'objective exchange value of money' of Mises is no more determined than the absolute level of prices of Wicksell: if the quantity of money substitutes can be modified with no limit and is therefore undetermined, so is the value of money. This is what Wicksell replied to Mises in 1914:

\footnotetext{
“As I see it, the entire matter is simple enough. Assuming a money economy, it is obviously the amount of cash needed which determines the demand for money. (...) Furthermore, if we imagine an economic system where each and every payment takes place simply by a transfer on the banks' books, so that the only measure of value is the unit in which these accounts are kept, then we can readily visualize an equilibrium of prices at any height. Thus the problem which Mises wants to solve 'first' does not exist at all; the question becomes merely one of trying to explain the cause of relative price shifts in an otherwise entirely normal configuration of prices.” (Wicksell 1914: 146; reprinted in Bien Greaves and Mc Gee, 1993, p. 197-98)
}

To sum up, the divergence between Wicksell and Mises concerning the relation between the money market and the commodity market regards the link between the value of money and the ratio of exchange between money and commodities. As we shall investigate now, this 
divergence will inevitably impinge on the way the two authors deal with the relation between the loan rate and the real rate of interest.

\section{2. Capital and interest theory: the interdependence of the 'loan rate of interest' and the 'natural rate of interest'}

Wicksell and Mises’ conceptions of capital and interest grew out of Böhm-Bawerk’s theory of capital: Mises was Böhm-Bawerk’s student and Wicksell attended some of his

seminars. Moreover, both authors criticized Böhm-Bawerk’s theory of capital, though on different grounds.

Wicksell's contribution to capital theory is outstanding. It is now commonplace to regard his book Value, Capital and Rent, published in 1892, as a major foundation of marginal productivity theory. However, this masterpiece of Wicksell is rather separated from his theory of the cumulative process, on which we are focusing in this article. Even in this restricted perspective, Wicksell’s capital theory is not easy to grasp, judging by the variety of definitions of the rate of interest to be found in IP and in Lectures II.

He first defined in IP the rate of interest in compliance with the Austrian tradition of capital theory, i.e., as the "[natural] rate of interest which would be determined by supply and demand if no use were made of money and all lending were effected in the form of real capital goods.” (Wicksell [1936] 1965, p. 102)

In this quotation, we are to understand the term 'real capital' as equivalent to real savings, i.e. savings in natura.

In the second volume of his Lectures, Wicksell now defines the 'normal' or 'natural' rate of interest as: 
"the rate of interest at which the demand for loan capital and the supply of savings exactly agree, and which more or less corresponds to the expected yields on the newly created real capital (...).” (Wicksell [1935] 1967: 192-93).

Now, by real capital, Wicksell means ‘mobile or free’ capital, i.e., additions to inventories (primarily of raw materials and wage goods) or, in other terms, capital which is not fixed or tied up in production ${ }^{12}$.

Wicksell provides a third definition of the normal or natural rate in his systematic exposition of the cumulative process in Chapter 9 of IP. As pointed out by Siven, Wicksell creates confusion in this chapter by giving the term 'natural rate' a meaning different from the rest of the book : "[An increase of the natural rate of interest] may be due, for instance, to a fall in the level of wages (brought about by a relative increase in the number of workers), or to a fall in the rent on land or of other rents, or finally to a rise in productivity of labour and natural forces as a result of technical progress.” (Wicksell [1936] 1965, p. 141). In other terms, in this passage, Wicksell likens the natural rate (or the difference between the natural rate and the contractual monetary rate of interest) to profits accruing to entrepreneurs in the first place.

Let us now turn to Mises’ capital and interest theory.

Mises' contribution to capital and interest theory is worth mentioning for at least two reasons. First, unlike other Austrians, such as Hayek, he developed a notion of capital that is fully consistent with the subjective theory of value and cost initiated by Menger. Second, while paying tribute to Böhm-Bawerk’s seminal role in the development of the timepreference theory, he sharply criticized the epistemological perspective from which BöhmBawerk viewed time as entering the analysis (see Festré 2003). Mises’ contribution to capital and interest theory is mainly found in Human Action (1949), except for one paper devoted to inconvertible capital in Epistemological Problems of Economics (1933). In Human Action, 
following the example of his Austrian predecessors, Mises points out that economists "erred in classifying ‘capital’ as an independent factor of production.” (Mises [1949] 1996, p. 493). He noted that:

\footnotetext{
“[The] fundamental distinction is between goods of higher and lower orders, between producers' goods and consumers' goods (...). The law controlling the determination of the prices of the factors of production is the same with all classes and specimens of these factors.” (Mises [1949] 1996: 640)
}

However, Mises’ conception of capital differs from that of Böhm-Bawerk and his followers. Firstly, he distinguishes capital goods from the broader notion of capital:

\begin{abstract}
"[Capital goods] are tools and half-finished products, or goods ready for consumption that make it possible for man to substitute, without suffering want during the waiting period, a more timeabsorbing process for another absorbing a shorter time (...) From the notion of capital goods one must clear distinguish the concept of capital. The concept of capital is the fundamental concept of economic calculation, the foremost mental tool of the conduct of affairs in the market economy." (Mises [1949] 1996: 260-61, emphasis added)
\end{abstract}

By this statement, we are to understand, as pointed out by Hayek, that Mises rejects BöhmBawerk's notion of real capital in order "to rehabilitate the [Mengerian] abstract concept of capital as the money value of the property devoted to acquisitive purposes against the Smithian concept of the 'produced means of production'.” (Hayek 1934a, p. 85). In addition, Mises criticizes Böhm-Bawerk’s notion of ‘average period of production’ for not recognising that time should enter into the analysis only in the ex ante sense ${ }^{13}$. The role that "time plays in action consists entirely in the choices acting man makes between periods of production of different length. The length of time expended in the past for the production of capital goods 
available today does not count at all (...). The ‘average period of production’ is an empty concept.” (Mises [1940] 1996, pp. 488-89). In other words, Mises emphasizes the teleological nature of time-preference as expressed by forward-looking decision made by producers and consumers.

Mises' conception of the rate of interest changed over time along with his treatment of capital. In his early TMC, he defines the natural rate of interest in Böhm-Bawerkian terms as:

\footnotetext{
“[t]he level of productivity of that lengthening of the period of production which is just justifiable economically and of that additional lengthening of the period of production which is just not justifiable; for the interest on the unit of capital upon whose aid the lengthening depends must always amount to less than the marginal return of the justifiable lengthening.” (Mises [1924]
} 1981: 399)

In his later Human Action, Mises uses the term ‘originary’ rate of capital to designate the discount of future as against present goods. Thus, the phenomenon of interest directly relates to time preference, with no more reference to Böhm-Bawerk’s natural rate of interest. As he writes:

\footnotetext{
"Originary interest is the ratio of the value assigned to want-satisfaction in the immediate future and the value assigned to want-satisfaction in remote periods of the future. It manifests itself in the market economy in the discount of future goods as against present goods. It is a ratio of commodity prices, not a price in itself.” (Mises [1949] 1996: 524-26).
}

In the above quotation, production is clearly conceived as an intertemporal exchange of goods. In other terms, since production takes time, the market prices of factors of production (which tend to be reflected in the market prices of the consumer goods they produce) are 
themselves subjected to time preference. Thus, in a production economy, the market generates interest as the excess value of produced goods over the appropriately discounted values of the relevant factors of production ${ }^{14}$.

Beyond variations of both authors regarding the definition of the "natural" rate of interest, Wicksell and Mises disagree on the relation between the real (or natural) rate of interest and the loan (or market) rate of interest. As Uhr indicates, for Mises, banks cannot for long maintain a loan rate lower than the natural rate of interest. If they attempt to do so, either the natural rate of interest is reduced to the level of the loan rate by real capital formation resulting from 'real saving', or as the price level rises, non bank creditors press for higher loan rates, and if the banks persist in maintaining the low rate against their wish, the system will spiral down toward a crises. (Mises [1924] 1981, pp. 355-65, Uhr 1960, pp. 256-57). This statement raises two problems: the question of capital formation through 'forced savings' on one hand, and the role of banks in the adjustment of the two rates.

Concerning the role of banks, Wicksell considers that this is not an important consideration. First, he always contended that the crisis, if nothing else, will force the banks to make the proper loan rate adjustment. For instance, in his systematic exposition of the cumulative process in chapter 9 of $I P$, he assumes a pure credit economy without outside money. Under these circumstances, since there are no reserve constraints, there is no room for bank intervention. However, in other passages of the same book, where he implicitly assumes a mixed inside and outside money economy, he emphasizes the existence of a positive correlation between the price level and the loan rate of interest. Thus, a higher price level would lead to external and internal drains and banks would have to increase the loan rate of interest in order to defend their reserves (Wicksell [1936] 1965 :113-14). 
In the second edition of his TMC, Mises points at those divergences in Wicksell's treatment of the role of banks in the adjustment of the two rates, considering that they constitute inconsistencies in his analysis. He first notes that Wicksell, though assuming as a starting point that only fiduciary media, i.e., bank notes or current accounts without gold backing, are in circulation and that their quantity is not legislatively restricted, then refers to the requirements of business for gold coins and banknotes - their demand increasing as the price level rises - in order to show that the banks must raise the rate of interest on loans (Mises [1924] 1981, pp. 395-96). He also refers to a passage of the Lectures where Wicksell claims that if the purchasing power of the commodity money is too low, it discourages the production of precious metals which serves as money, but increases, ceteris paribus, their industrial consumption, so that the deficiency which would arise as soon as consumption begins to exceed production has to be made up from bank reserves (Wicksell, [1935] 1967, p. 113-14, Mises [1924] 1981, p. 396). According to Mises, these circumstances, which may be effective in the case of commodity money, are not relevant anymore in a so-called 'pure credit economy’ (Mises [1924] 1981, p. 396) ${ }^{15}$.

Nevertheless, these contradictions do not alter Wicksell's broader message which rests on the crucial assumption that the main disturbances are not of monetary origin, but lie in productivity changes. By contrast, for Mises, the cycle is indeed initiated by an exogenous shock: the issuing by banks of new fiduciary media, which causes the loan rate of interest to fall (Ibid. p. 391). This certainly constitutes a crucial divergence between Mises and Wicksell.

Concerning the second question, i.e., capital formation through forced savings, Wicksell observes:

\footnotetext{
"Mises forgets that under conditions of economic equilibrium the length of the actual periods of production must always yield the greatest possible gain on his capital to the individual
} 
entrepreneur. If he can borrow money at a considerably lower rate, he needs not lengthen the production period on account but can very quietly pocket the difference as an extra gain. On the other hand, if he is led to expand his enterprise, wages are driven up by the competition of other entrepreneurs and, if commodity prices were to remain the same, this would certainly compel to lengthen the periods of production concerned.” (Wicksell 1914: 148, reprinted in Bien Greaves and McGee, 1993, pp. 198-99).

In other terms, if we assume that entrepreneurs use an optimal production period before the loan rate becomes low, then they will continue to produce for a while with the same length of production period. Meanwhile, they will merely pocket the gain resulting from the credit obtained at less expense than they had counted on. This gain then will induce them to extend their operations in the next period in the sense of widening the capital structure. This attempt at widening will force them to bid up wages in competition with one another. Now, if prices remain constant, the increase in wages would reduce the real rate and induce entrepreneurs to offset this tendency by lengthening the period in the sense of deepening the capital structure. But prices do not remain constant. Instead they rise, because real capital -the subsistence fund- has not increased appreciably in so short a time. In fact, the subsistence fund may have decreased since the loan rate, as an inducement to saving, has been reduced. Moreover, in the meanwhile, money wages and rents have risen. Thus as prices rise, entrepreneurs are again in a position to continue making gains despite higher wages and rents. Consequently, they are not forced to extend the capital structure in the vertical dimension, and thus the real rate does not fall. In this way, "increased money must necessarily call forth a corresponding increase in commodity prices (...) As a result, in spite of the increased money loans, the entrepreneurs find themselves no better off than before.” (Wicksell 1914: 148, reprinted in Bien Greaves and McGee 1993, p. 199). 
But if entrepreneurs are ultimately forced to resort to extend the production period, then, “according to Böhm-Bawerk’s theory, this would lead also to a lowering of the natural rate of interest on capital, so that the previously existing difference between the two rates would soon disappear.” In these circumstances, “the upward movement of prices would necessarily cease.” (Wicksell 1914, p. 147, reprinted in Bien Greaves and McGee 1993, p. 198). At this stage Wicksell discards the possibility of capital accumulation through forced savings. However, as we shall point out, he will later make a concession to Mises, stating that forced saving could induce the real rate of interest to decrease and, hence, the upward movement of prices to continue. We shall now show how Wicksell's framework of the cumulative process in its simplified version as found in chapter 9 of IP could not account for such a possibility, while Mises’ analysis of business cycles clearly allows one to deal with forced savings and capital accumulation.

\section{WICKSELL AND MISES ON PRICE 'DISEQUILIBRIUM' DYNAMICS}

In this section we will describe and contrast the dynamics to which the divergence between the natural rate and the loan rate of interest gives rise to in Wicksell's and Mises' analyses. In particular, we shall emphasize how their respective position on the issue of the interdependence of both rates leads each to develop alternative explanations of price movements. Moreover, we shall deal with their respective treatments of capital accumulation and income distribution as well as of the role of the banking system in economic dynamics. 


\section{1. Wicksell's framework of the 'cumulative process'}

In Wicksell's simplified framework of the cumulative process, as exposed in chapter 9 of $I P$, the period of production is fixed, workers and landowners are paid in advance at the beginning of the year, factor-market clearing occurs before goods-market clearing within the production period, so that, the increase in factor prices do not prevent entrepreneurs to continue producing on the same basis.

At the beginning of year $t$, the entrepreneurs borrow from the bank and hire workers and land. At the next step, before the production process starts, workers and landowners use their income to buy consumer goods from the capitalists / dealers, thus turning their money wages into real wages, and thus fixing the price of consumption goods on their market. During year $t$, production takes place but no transactions are made. At the end of year $t$, the entrepreneurs sell their product to the capitalists / dealers at the same price as the price fixed on the consumption good market at the beginning of the year and repay their debt to the bank. Price expectations are static, so that when entrepreneurs hire factors of production at the beginning of the year $t$, they expect to be able to sell the goods at the point of time at the same price as the one fixed in year $t-1$. Now, if the money rate of interest fixed by the bank is lower than the real rate of interest, then, entrepreneurs make extra profits in kind, which induce to ask more finance the next year. Money wages are thus increased and, therefore, the price of consumption goods: the cumulative process is under way and will continue as long as the divergence between the two rates is maintained.

However, in some other passages of $I P$, Wicksell modifies this assumption by allowing non-stationary price expectations. Under these circumstances, the cumulative process appears to be exponential: 
“The upward movement of prices will in some measure 'create its own draught'. When prices have been rising steadily for some time, entrepreneurs will begin to reckon on the basis not merely of the prices already attained, but on a further rise in prices.” (Wicksell [1936] 1965: 96).

In another passage of $I P$, he notes that:

“(...) as soon as (...) [entrepreneurs] start reckoning on a future rise in prices, the actual rise will become more and more rapid. In the extreme case in which the expected rise in prices is each time fully discounted, the annual rise in prices will be indefinitely great.”(Wicksell [1936] 1965: 148, emphasis in the original)

In such a case, i.e. when the elasticity of price expectations is greater than unity, the process becomes unstable even if there is no divergence between the two rates. ${ }^{16}$ Wicksell was aware of this possibility and provided obscure reasons for the upward process to settle down as soon as the initial divergence disappears. He noted that:

“(...) it is not to be supposed that there will be any cumulative movement of prices in the manner of an avalanche. Through its influence on supply and demand, an expectation of a rise in prices in the future is by its very nature capable in itself of bringing about only a somewhat smaller rise than is actually expected. For a buyer could not obtain any profit if the whole of the expected rise were included in the actual price, and the seller will almost always prefer a smaller but more secure profit to a profit which is somewhat larger but less certain.” (Wicksell [1936] 1965: 97)

In this passage, Wicksell presumably refers to capitalists / dealers as the buyer and to entrepreneurs as the seller. But the possibility for entrepreneurs to accept a lower profit implies a modification of the rule of price determination assumed in the simplified version of the cumulative process. Indeed, one can notice that within the period of production, two types of monetary transactions take place sequentially: the transaction between the 
capitalists / dealers and the workers at the beginning of the year $t$; then, the transaction between the capitalists / dealers and entrepreneurs at the end of year $t$. Those two types of transactions do not however obey to the same rule regarding the formation of prices. The first one is a classical one: price flexibility adjusts demand and supply of consumer goods. But the second one involves a fixed-price rule, so that quantity rationing may occur. Either the capitalists / dealers cannot afford to buy the totality of goods at the price fixed by the entrepreneurs and then, the entrepreneurs make profits in kind, or if the money rate is higher than the real rate of interest, capitalists / dealers obtain less goods than they were ready to buy at the fixed price (assuming zero stocks of consumer goods) and, in this case, entrepreneurs are not able to reimburse their loans to the bank in monetary terms.

Now, if one allows price flexibility for the transaction between the capitalists / dealers and the entrepreneurs, no cumulative movement is set into motion and Wicksell's main conclusion collapses. In this case, entrepreneurs cannot obtain any real profit (in kind). The only implication is that there are now two levels of prices for consumer goods: one at the beginning of the year and another one at the end of the year.

This has some implications concerning income distribution. In fact, what appears is that, in Wicksell's framework of the cumulative process, not only the price level is left undetermined but also income distribution since the latter depends on the way profits in kind can be converted into monetary profits as well as on the rules of price determination in the transactions between the capitalists / dealers and the workers on one side and between the entrepreneurs and the capitalists / dealers on the other side (see Dupont and Reus 1996, pp. 158-59).

Nevertheless, in some other passages of Interest and Prices as well as in his Lectures (Wicksell [1936] 1965, pp. 120-21; Wicksell [1935] 1967, p. 195), Wicksell explicitly refers to a two-sector economy. For instance, in IP, he writes: 


\footnotetext{
“The transition from hoarding to modern forms of saving introduces further peculiar phenomena. If banks are opened in a country which formerly possessed none, and in which the greater part of the money was hidden in "safes and coffers", then this part of the money is put into circulation, and the consequence is, apart from increased enterprise, a more or less marked rise in prices. The latter is, in fact, a necessary condition of the former, for the enforced general reduction of consumption that results from it constitutes just that accumulation of real capital, which is the indispensable preliminary to a higher degree of capitalist production. In other words, increased enterprise withdraws some labour and natural resources from the production of present commodities in order to employ them in preparation for future production, and this would be impossible in the long run if present consumption were not restricted in the same degree.” (Wicksell [1935] 1967: 14).
}

In this quotation, Wicksell introduces the possibility of capital accumulation, which was not possible in his systematic exposition of the cumulative process where there is only one good. As soon as an explicit sector for capital goods is allowed for, one should expect that Wicksell would deal with the maladjustments the cumulative process can generate in the capital structure as well as well as their impact on employment and income. In particular, as noted by Hicks, in Wicksell's broader analysis of the cumulative process, the existence of a disequilibrium stage involving different movements of capital good prices and consumer goods prices is undeniable (Hicks 1967, p. 66). In other terms, starting from Wicksell's general assumption of an increase in productivity giving rise to a positive discrepancy between the natural rate and the loan rate of interest, the cumulative process should be characterized, if full employment prevails, by rising values of durable capital goods. But Wicksell generally denies the possibility of such expansion. This is particularly clear in his answer to Davidson in 1909 in the Ekonomisk Tidskrift, where he explains that Davidson's conjecture, i.e., a fall in commodity prices following the increase in productivity, thus 
restoring the level of the natural rate to the loan rate of interest, is not possible because the expansion of production is only "a thing of the future", while the "enhanced prospects for profits take place immediately” (Wicksell [1909] 1999, p. 41). He indeed does not agree with Davidson's tacit assumption that the increase in productivity, through an increase in real wages, should give rise immediately to an increase in real capita. On the contrary, Wicksell assumes that "real capital and real wages do not undergo any change” (Ibid, p. 42). Under these circumstances, even if prices fall, money wages must also fall and, therefore, the entrepreneur would have the same return as if prices had remained constant.

Later in 1915, on the occasion of the publication of the second Swedish edition of Lectures-II, Wicksell however made the following concession :

"I do not feel that it has been necessary for me to modify my general position, unless one considers as such a certain concession towards my critics concerning the mutual influence of the money rate and the natural rate of interest on one another.” (Translated by E. Sommarin in the Preface to the fourth Swedish edition of Wicksell's Lecture-II, p. viii).

“The objection has been raised to the whole of the above reasoning, that a lowering of the loan rate must also depress the real rate so that the difference between them is more and more leveled out and thus the stimulus to a continued rise in prices eliminated. This possibility cannot be entirely rejected. Ceteris paribus a lowering of the real rate unconditionally demands new real capital, i.e. increased saving. But this would certainly occur, even if involuntarily, owing to the fact that higher prices would compel a restriction of consumption on the part of those who had fixed money incomes. (...)

Against this, however, would have to be set the decrease in voluntary saving which a lowering of interest rates tends to produce. But if the former influence prevails and if production is unable to absorb unlimited quantities of new capital without a reduction in net yield, then the incipient rise in prices though it would certainly not recede, might yet be arrested, unless the banks reduced their rates still further.” (Wicksell [1935] 1967: 198-99) 
This passage suggests a turnaround in Wicksell's position since he now seems to endorse the idea that 'forced saving' would outweigh the reduction in voluntary saving caused by a decline in loan rates ${ }^{17}$. Wicksell did not, indeed, consider voluntary saving to be highly interest-elastic. Assuming voluntary saving to have unit elasticity relative to interest rates, a reduction of a normal loan rate of $6 \%$ to a subnormal one of $4 \%$ would then reduce voluntary saving by about 33\%. If money wages and rents rise as a result of the rate reduction while output of consumption goods is reduced somewhat because of increased capital formation by entrepreneurs, then the normal consumption expenditure stream will now be swelled by the increase in money wages and rents as well as by the reduction in voluntary savings, with the result that prices of consumption goods rise relatively fast. Consequently “forced saving” becomes of significant magnitude almost from the outset and increases cumulatively with the upward process.

Moreover, in the event of a rise in the real rate with the loan rate held constant - and Wicksell considered such cases to be more likely starting points for upward processes than direct loan rate reductions taken on the initiative of banks - there would be no reduction in voluntary savings to act as an offset to the forced savings the process generates, so that forced saving would presumably be matched by a equivalent amount of net capital formation. Thus his ‘concession’ was substantial. A later interpretation of it by Lindahl shows clearly the modification it called for. Lindahl concluded that the result of a typical Wicksellian cumulative process might readily be a self-generated new equilibrium achieved via the effect on the real rate of capital formation from 'forced savings'. But this would only be possible if entrepreneurs are not guided by expectations of future price increases. On the other hand, if they act on such expectations, the cumulative process may continue indefinitely until it is 
brought to an end by a crisis, in the course of which the loan rate is adjusted to the level of the real rate (Lindahl 1939, pp. 180-82).

To summarize, Wicksell’s reply to Davidson's stress on the possibility of a parallel and simultaneous movement of the real and the loan rate of interest was indirect. He was satisfied to point out that his real rate was defined as an expected rate of return on real capital formation, a rate that is essentially variable, and to add that its variations were sufficient to account for those price level fluctuations, which were not due to 'autonomous causes', such as variations in the quantity of gold for instance (Wicksell [1935] 1967, p. 200). The point that was implicit in his position was made explicit some years later by Myrdal who said in substance that the sufficient condition for the cumulative process is that the real rate viewed ex ante should be capable of varying independently of the loan rate (Myrdal 1939, pp. 54ff). The necessary condition was, of course, that there be some lag in the adjustment of the two rates to one another. The length of the ensuing process would depend on the duration of this lag. Mises' extension of Wicksell's cumulative process relies precisely on the existence of such lags. Moreover, his focus on relative price movements will open the way for the development of a business cycle theory.

\section{II.2. Mises's business cycle theory}

Mises’ business cycle theory has undergone some modifications through time. The first version, as developed in $T M C$, is more concentrated on the variations of relative prices following an increase of the issue of credit media while the later versions, all contained in Human Action, move the analysis towards the consideration of the role of price expectations in the development of the cycle. 
As already emphasized, Mises’ TMC is focused on the connection between variations in the objective exchange value of money and variations in the rate of interest. More precisely, Mises distinguishes between two kinds of influence on the rate of interest that may result from an increase of the issue of fiduciary media by banks. The first one is indirect and permanent because it operates through the displacements in the social distribution of income and wealth, which occur as a consequence of variations in the objective exchange value of money. This influence may be both ways, i.e. cause the interest rate to decrease (or to increase) depending on whether the new distribution of income and property is more (or less) favourable to the accumulation of capital (Mises [1924] 1981, p. 400).

The second kind of influence is directly related to the business of banking. Mises notes that the new fiduciary media coming on the loan market constitute "an additional supply of present goods”, which consequently “tend to cause the rate of interest to fall.” (Mises [1924] 1981: 391).

Starting from an equilibrium position where the loan rate of interest is identical to the natural rate of interest, the cycle is therefore initiated by banks issuing new fiduciary media, which causes the rate of interest on capital to fall below its natural level. Assuming full employment and decreasing returns on capital, the decrease of the rate of interest on capital is necessarily followed by a lengthening of the ‘average’ period of production. However, this lengthening of the 'average' period of production is sustainable only if the means of subsistence have increased sufficiently to support the workers and entrepreneurs during the whole period of production. Otherwise, the trend towards increased productive activity will prove to be unsustainable. Mises contends that "a time must necessarily come when the means of subsistence available for consumption are all used up although the capital goods employed in production have not yet been transformed into consumption goods.” (Mises [1924], 1981, p. 400). The implementation of more roundabout processes of production will 
cause the price of goods and wages to rise since there has been no increase of intermediate products. Moreover, Mises supposes that the pressure on production goods is greater than that on consumption goods, since the prices of the latter, although they rise, do it in a moderate degree, namely, “only insofar as they are raised by the rise in wages."18 (Mises [1924] 1981, p. 401). The tendency toward a fall in the rate of interest on loans that originates in the policy of banks is thus at first strengthened. In other words, the objective exchange value of money does not fall enough as to induce the adequate adjustment (increase) of the loan rate of interest.

Mises then describes the turning point of the cycle as a reversal of the relative price movement: a counter-movement will set in, i.e., the prices of consumption goods will rise while those of production goods will fall. Therefore, the rate of interest on capital will rise, thus approaching the natural rate (Mises [1924] 1981, p. 401). Mises’ explanation runs as follows: the implementation of more roundabout processes of production implies the transfer of intermediate goods as well as labour from their previous employment in shorter processes of production, i.e., those producing consumption goods, which are now activated at a reduced scale. Since no change in the consumption needs of the wage earners is involved, the effect of this is an increase in consumption goods' prices ${ }^{19}$. This tendency is now strengthened by the decrease in the objective exchanged value of money following the increase of fiduciary media issued by the banking system. This reinforcing effect on the rate of interest on capital results from transitory movements in the objective exchange value of money that are linked to the fact that "variations in the exchange value of money do not appear everywhere simultaneously and uniformly, but start from a particular point and only spread out gradually throughout the market.' (Mises [1924] 1981, p. 387). More precisely, Mises notes that it is the entrepreneurs who generally benefit from the increase of the issue of fiduciary media. Therefore, if the objective exchange value of money alls, the entrepreneurs gain in the short run since '[they] 
will be able to meet part of [their] expenses of production at prices that do not correspond to the higher level, while, on the other hand, [they] will be able to dispose of his product at a price that is in accordance with the variation that has meanwhile occurred.” (Mises [1924] 1981, p. 387). This circumstance cannot fail to have an effect on the interest rate on loans. Indeed, those entrepreneurs who benefit from inflation, i.e., those that are up the scale of goods, are prepared if necessary to pay a higher rate of interest, and the competition of other would-be-borrowers, who are attracted by the same prospects of profits, will accept the higher rate. This means that the rate of interest on loans rises. Thus, the structure of relative prices which is determined by the state of the capital market and has been disturbed by the intervention of the banks will be approximately re-established, provided that entrepreneurs have static expectations ${ }^{20}$.In contrast to Wicksell, Mises makes it clear that any action from the banks in order to offset the automatic rise in the loan rate of interest will be useless. He notes:

\footnotetext{
“At first, the banks may try to oppose these two tendencies [due to the insufficient supply of consumption goods and reinforced by the fall in the objective exchange value of money] by continually reducing the interest rate on loans and forcing fresh quantities of fiduciary media into circulation. But the more they thus increase the stock of money in the broader sense, the more quickly does the value of money fall, and the stronger is its countereffect on the rate of interest.” (Mises [1924] 1981: 402).
}

In Monetary Stabilization and Cyclical Policy (1928) as well as in Human Action (1949), Mises describes the origin of expansion as in his early TMC: the cycle starts with the release of an additional supply credit permitted by the issue of fiduciary media, i.e., bank notes without gold backing or current accounts, which are not entirely backed by gold reserves. This produces a decrease of the rate of interest, which stimulates economic activity. Some 
new projects, which would not have been thought profitable if the rate of interest had not been influenced by the manipulation of banks, are now initiated.

With respect to the propagation mechanisms, Mises now switches his emphasis to the consideration of the mechanism of the price premium. This change reveals his intention to account for individuals’ price expectations. In the TMC, Mises indeed implicitly assumes that the loan rate of interest determines the rate of interest, i.e, the rate of exchange between present goods and future goods. Conversely, every change in the price ratio between production goods and consumption goods impinges on the loan market, which automatically adjusts, with some lag, to monetary changes. In Human Action, things become different. Mises now focuses on the rate of originary interest, which he defines as the ratio between prices of present and of future goods. But this rate can only coincide with the rate of interest on loans in the imaginary construction of the 'evenly rotating economy ${ }^{21}$, . In this case, "we may call this rate the neutral rate of interest.” (Mises [1949] 1996, p. 538). In every situation where the 'money relation' - i.e., the ratio between the demand for and the supply of money for cash holdings - is changed, the ensuing modifications in the wealth and the income of individuals alter the level of originary interest. Thus, the driving force of money has the power to bring about lasting changes in the final rate of originary interest (Mises [1949] 1996, p. 538). By this we are to understand that there cannot be any conceivable uniform rate of originary interest in a changing economy and that there is no more permanence in the rate of originary interest than in prices and wage rates:

\footnotetext{
"In the changing economy, the rate of interest can never be neutral. In the changing economy, there is no uniform rate of originary interest; there only prevails a tendency toward the establishment of such uniformity. Before the final state of originary interest is attained, new changes in the data emerge which divert anew the movement of interest rates toward a new final
} 
state. Where everything is unceasingly in flux, no neutral rate of interest can be established.”

(Mises [1949] 1996: 542)

Furthermore, the loan rate of interest is not any longer considered as determining the current rate of interest as it is manifested in the ratio of prices of present over future goods. Mises notes that:

\footnotetext{
"The loan rate does not determine the rate of interest. It adjusts the rate of interest on loans to the rate of originary interest as manifested in the discount of future goods.” (Mises [1949] 1996: 527)
}

What now plays the same role as the loan rate of interest in the TMC is the 'gross rate of interest' as it already appeared in Mises’ 1936 article: “The 'Austrian’ Theory of the Trade Cycle.” This rate should not be confused with the originary rate of interest or the rate of interest on capital. There are in fact as many gross rates of interest as they are individual debt contracts so that gross market rates are not pure interest rates (Mises [1949] 1996, p. 539). In other terms, the gross rate of interest incorporates the uncertainty component of both parties of the contract. On one hand, the lender is always faced with the possibility that he may loose a part or the whole of the principal lent. On the other hand, the borrower commits part of his fortune or the collateral as a buffer between the creditor and himself (Mises [1949] 1996, p. 540). Mutual appraisal of these dangers determines the conduct of both parties in bargaining about the terms of the contract.

Moreover, the gross market rate of interest also incorporates a price premium, i.e., a negative or positive addendum to the net rate of interest in order to account for individuals’ price expectations. However, as Mises points out, the price premium can never offset the changes in the 'money relation' because its appearance always occur after those changes and can never precede them (Mises [1949] 1996, p. 544). Furthermore, the price premium always 
lags behind the initial change in the supply of money since it can only react to "the necessary later occurring effects of these changes upon the price structure.” (Mises [1949] 1996, p. 545). This point is worth emphasising since it permits a better understanding of the sequence of the cycle.

The development of the cycle can be sum up as follows. Similarly to Mises’ description in the TMC, the movement begins with credit expansion by banks, which induces the gross rate of interest to fall. At this stage, no positive price premium arises since it can appear only after the additional supply of money (in the broader sense) has run its effects on the prices of commodities and services. Mises notes:

\footnotetext{
“(...) if such changes in the money relation affect first the loan market, they bring about just the opposite changes in the configuration of the gross market rates of interest. While a positive or negative price premium would be required to adjust the market rates of interest to the changes in the money relation, gross interest rates are in fact dropping or rising (...) [The operation of the instrumentality of the price premium] begins too late, it lags behind the changes in purchasing power (...).” (Mises [1949] 1996: 548)
}

Then, the drop in the gross market rate of interest affects the entrepreneurs' calculation about the probability of success of the investment projects they are considering to undertake: "along with the prices of the material of productions, wages rates, and the anticipated future prices of the products, the gross rates of interest show [them] what investments can be made under the given state of the ratio in the public's valuation of future goods as against present goods.” (Mises [1949] 1996, p. 552). Now that the decrease in the gross rate of interest has altered the calculations of entrepreneurs, some new projects appear to be profitable. Entrepreneurs then embark upon their realization. A boom begins.

At this stage, the problem arises as to how the gross market rate can adjust the originary rate of interest. As credit expansion continues on the loan market, a pressure is felt on the 
gross market rate of interest, which now would have to rise so as to take into account the positive price premium. This process goes on as long as the expansionist movement runs its course. Since the unceasing rise of the gross market rate cannot catch up with the originary interest augmented by the positive price premium, this inevitably induces further economic expansion as the one describe in the TMC: the vertical expansion of the structure of production first favors the prices of producers' goods, thus bringing a tendency towards a fall in the originary rate of interest.

Concerning the reversal, Mises now accounts for the possibility of hyperinflation. Under these circumstances, the situation is now more worrying than in the TMC since price expectations do not only reflect the previous inflation rate but also regard the future state of the market (Mises [1949] 1996, p. 545). This circumstance leads to an even more drastic fall in the objective exchange value of money. In this case, prices rise at a greater pace than the growth of money and the loan rate of interest can then rise without bounds since the unceasing rise of the gross market is unable to catch up with the originary interest augmented by the positive price premium. During periods of hyperinflation, this process can even lead to the destruction of money. As Mises notes:

\footnotetext{
"It is necessary to realize that the price premium is the outgrowth of speculations anticipating changes in the money relation. What induces it, in the case of the expectation that an inflationary trend will keep on going, is already the first sign of the phenomenon which later, when it becomes general, is called 'flight into real values' and finally produces the crack-up boom and the crash of the monetary system concerned.” (Mises [1949] 1996: 544)
}

In other words, although increasing, the gross market rate is still too low for bringing about the required adjustments in the 'money relation'. As Mises indicates, 'the banks believe that they have done all that is needed to stop 'unsound' speculation when they lend on more 
onerous terms (...) [But] they fail to see that in injecting more and more fiduciary media into the market they are in fact kindling the boom.” (Mises [1949] 1996, p. 558).

\section{CONCLUDING COMMENTS}

Our re-reading of Wicksell and Mises in the light of the debate that divided them in 1914 allows us to express several concluding comments.

The main divergence between Wicksell and Mises concerns price movement dynamics, with Wicksell focusing on the dynamics of the general level of prices during the cumulative process, while Mises stresses the relative price dynamics in his business cycle analysis. This difference can be explained by the fact that Mises' endeavor was to integrate Wicksell's analysis of the divergence between the natural and monetary rate of interest with real dynamics. On the contrary, Wicksell predominantly focused on monetary theory and, therefore, chose the context of a stationary state to facilitate his analytical project. Wicksell's cumulative process is indeed prevalently monetary. His general assumption of an increase in productivity as the starting point of his analysis is introduced mainly to permit the emergence of a positive gap between the natural and the monetary rate. One must remember that at the beginning of the cumulative process productive factors are fully employed. Therefore, this positive gap only creates a tendency to the increase of the national output and does not imply an actual variation. Therefore, if the cumulative process may terminate in a crisis of hyperinflation or deflation, it is clear that the maladjustment it may generate in production, in the capital structure and with respect to employment and income distribution are on the whole ignored by Wicksell. As noted by Uhr, one of the most informed commentators of Wicksell's economic theory: 


\begin{abstract}
“It is evident that Wicksell's models left much to be desired. The main difficulty with them was that they were too near-static in nature, and that the economy confines to producing only consumption goods, left no room for introducing changes in the structure of capital or in the length of the period of investment.
\end{abstract}

The upward process, which is stalled if entrepreneurs sell the increased output at a reduction in price, can only get off dead center if the dimension of capital structure or of the period of investment are variable. The increased in productivity that raises the natural rate above the loan rate may then become the occasion for introduction of longer production processes by shifting some resources from production of consumption goods to production of intermediate goods.” (Uhr 1960: 245)

Moreover, as Boianovsky (1995) recently wrote, Wicksell was aware of the opposition between static and dynamic economic analysis in economics and realized that he was unable to give a contribution to the second one. This is why he limited his analysis to stationary states and uniform growth paths (Boianovsky 1995, pp. 378-83). As Boianovsky again noted, he even expressed his doubts concerning the possible project of building a business cycle theory (Boianovsky 1995, p. 376). It should not be surprising, therefore, that in the second edition of the first volume of his Lectures, he described the theory of the trade cycle and crises as a "field which is still the darkest in the whole province of economics" and noted that "we have, throughout [this volume] restricted our observations to the economic phenomena of equilibrium in the ordinary sense -to static analysis as distinct from dynamic” (Wicksell [1911] 1934, p. 221, quoted by Boianovsky 1995, p. 397).

By contrast, Mises explored the route that Wicksell was reluctant to follow. This lead him to deal with the issue of capital accumulation through forced savings which opened the way for Hayek’s systematic treatment in Prices and Production.

These divergences could be considered only from the viewpoint of economic historiography. On one hand, Wicksell’s position may open the road to an interpretation, 
which favours a disequilibrium dynamics framework. Keynes’ Treatise on Money offers an interesting example of this first interpretation. Keynes assimilated Wicksell's natural rate to an expected rate of return on investment and his British institutional viewpoint convinced him to argue that the monetary rate of interest was governed by financial markets. This re-reading allowed Keynes to build a monetary theory of the business cycle based on disequilibrium dynamics. On the other hand, Mises' interpretation of Wicksell forbids such an analytical possibility. The only possible re-construction, which remains within Mises’ framework, is a dynamic scheme based on the concept of equilibrium in which business cycles appear to be the result of a temporary deviation from the "natural" state. This is obviously the direction the Austrian tradition will follow, with the exception of Schumpeter, who transcended the cleavage between monetary and real analysis. From this perspective, the two main differences we stressed between Wicksell and Mises’ monetary conceptions appear to be at the origin of the opposition between two major approaches to money and business cycles during the twentieth century.

\footnotetext{
${ }^{1}$ Mises' Theory of Money and Credit is seldom considered as a genuine contribution to the development of the Austrian theory of business cycles. Apart from Rothbard who is laudatory to the point of writing that "the Austrian theory of money virtually begins and ends with Ludwig von Mises' monumental Theory of Money and Credit published in 1912” (Rothbard 1976 1946, p. 160), Mises’ contemporaries did not pay much attention to his work. Hayek notes, with some irony, that Mises' book received a curious review by Keynes “who could not suppress a somewhat envious expression of admiration for the erudition and philosophical breadth of the work, but who unfortunately, because, as he later explained, he could understand in German only what he knew already, did not learn anything from it” (Hayek 1992 [1956], p. 131). More recently, many commentators underestimate Mises’ work in money and business cycles.

${ }^{2}$ Bellofiore pointed out that Gustavo del Vecchio was the first to mention the debate between Wicksell and Mises (Bellofiore, 1998, fn 49, p. 569). An English translation of Wicksell's review is now available in Bien Greaves and McGee (1993) but we will also refer to the comments concerning the debate provided by Wicksell's
} 
bibliographer Uhr in his 1960 book.

${ }^{3}$ As pointed out by Bellofiore (Bellofiore 1998, p. 569, fn. 49), even to-day, commentators hardly refer to Wicksell's review of Mises' book. For instance, Laidler, who rightly connects Mises’ first moves toward the Austrian theory of the cycle with the fact that "Mises not[ed] the crucial role played by a commodity money in restoring equilibrium between Wicksell's money and natural interest rates, and not[ed] that this particular institution, through highly desirable, did not seem essential to the economic system.” (Laidler, 1991a: 299). However in another publication of the same year, Laidler asserts that the first edition of the Theory did not contain that specific combination of Wicksell plus forced saving that is the prototype of the Austrian theory of the cycle (Laidler 1991b, p. 152).

${ }^{4}$ After having considered that the natural rate was independent from the monetary rate, Wicksell made this concession at the prompting of Mises' and Davidson's criticisms in the second Swedish edition of the Lectures (1915).

${ }^{5}$ Some of them have been translated and printed in Erik Lindahl (ed), Selected Papers on Economic Theory, George Allen and Unwin, London (1958) and in Bo Sandelin (ed), Selected papers in Economics, vol. II, Routledge, London (1999).

${ }^{6}$ We also refer here to Wicksell's discussion on the real balance effect in the beginning of Interest and Prices. He explicitly notes that "the exchange of commodities in itself (...) affect only relative prices: they can exert no direct influence whatever on the absolute level of money prices." (Wicksell [1936] 1965, p. 23, emphasis in the original).

${ }^{7}$ In this Mises anticipated Patinkin’s concept of 'real balances'. See Moss (1976), who however notes that this idea is not consistent with Mises' focus on forward-looking decisions by heterogeneous individuals. Indeed, the agents cannot decide the extent of their monetary needs (i.e., the size of their cash balances) without knowledge of the whole array of market prices (Moss 1976, p. 22).

${ }^{8}$ Mises distinguishes between two types of money substitutes: ‘money certificates' and 'fiduciary media'. The former are wholly covered by money in the narrower sense (i.e. money proper in the usual sense including fiat money) while fiduciary media (i.e. bank notes and current accounts) are not. But both types of money substitutes serve the same purpose as money proper since they are convertible and secure claims to payments. They then add to the total quantity of money in circulation (Mises [1924] 1981, p. 155). This distinction echoes the opposition made by Mises between the commodity credit and the circulation credit. The former corresponds to "those credit transactions which are characterized by the fact that they impose a sacrifice on that party who 
performs his part of the bargain before the other does-the foregoing of immediate power of disposal over the exchanged good, or, if this version is preferred, the foregoing of immediate power of disposal over the surrendered good until the receipt of that for which it is exchanged.” By contrast, the second kind of credit transaction is "characterized by the fact that in them the gain of the party who receives before he pays is balanced by no sacrifice on the part of the other party.” (Mises [1924] 1981, p. 297).

${ }^{9}$ Even if Mises did not consider himself as an adherent of Böhm-Bawerk’s theory of interest, he regards it as a satisfactory solution to the problem. In particular, he recognizes that Böhm-Bawerk was the first to clear the way that leads to understanding of the problem; he was the first to make it possible systematically to relate the problem of interest to that of the value of money (Mises [1924] 1981, footnote p. 378).

${ }^{10}$ On this point, Mises adopts Menger's classification of goods according to which goods are evaluated in relation to their relative distance from final goods. Present goods are consumption goods, or goods of first-order, the value of which depends on the expected utility from consumption. Goods of higher-orders comprise the set of heterogeneous intermediate goods that are gradually incorporated within the process of production. Their respective values are determined by a process of imputation back to the lower order goods, in accordance with the marginal contribution they make to the production of final goods.

${ }^{11}$ This point is emphasized by Bellofiore (1998, p. 567) against Gootzeit who instead gives an interpretation of the expansion phase, which is very similar to Wicksell's cumulative process, that is with no variation of the relative price between consumption goods and production goods, and explains the reversal and the realignment of the two interest rates as the result of the pressure of demand for loans.

${ }^{12}$ C. Uhr, who translated Wicksell’s 1907 article on business cycles, reprinted in IP (1936), provides a clarification of the term 'mobile capital'. He notes that sometimes, Wicksell treats the terms savings and 'mobile or free' capital as synonymous, while at other points in his argument, he deals with them as distinct concepts. This can be explained, according to Uhr, by the fact that for Wicksell, "inventories, or 'free and mobile capital', exist primarily for 'conversion into' -i.e., as raw materials for and as subsistence means for sustaining those who furnish the labour and land required for production of- real capital.” (Uhr’s note in Wicksell [1936] 1965, pp. 226-27). In other terms, the supply of 'mobile and free capital', which presupposes a corresponding rate of saving, is a necessary prerequisite for carrying out the planned formation of fixed real capital. From this perspective, inventories can be viewed as 'mobile capital'. But what Wicksell means by 'free capital' is not savings in the usual sense but rather "capital which is not invested for long terms in specialized capital goods". (Ibid pp. 226-27). It should also be pointed out that the notions of investment and savings applied by Wicksell is 
in line with the Classical (Smith-Ricardo) tradition and this is the main reason why they differ so sharply from their more recent meanings.

${ }^{13}$ See Kirzner 1990, p. 55.

${ }^{14}$ See Kirzner [1976] 1990, p. 95.

${ }^{15}$ Wicksell indirectly replied to Mises in his Review of the TMC, stating that "[i]f we actually had a such ideal banking setup - which of course could appear only upon the discontinuance of free gold coinage - the difference between the 'natural' and market interest rate would be the only regulator of commodity prices. But certainly under present circumstances the banks are not free to set interest policy; a too-low discount would soon drive prices up so that the bank reserves would be endangered by the increased demand for metallic money.” (Wicksell 1914, p. 147. Reprinted in Bien Greaves and McGee 1993, p. 198). Certainly, there is no real inconsistency in Wicksell's analysis concerning this question but rather an emphasis on behalf of Mises on the case of a pure credit economy, while Wicksell discusses different models; sometimes pure inside (or outside) money systems, sometimes a mix system of inside and outside money.

${ }^{16}$ On this point, see also Hicks 1939, p. 251-55. With Wicksell's assumption of expectation elasticity equal to 1, i.e., any change in current prices is expected to be a permanent change, "the system can come to an equilibrium at any level of money prices" so that, "the possible discrepancy [between the money rate and the natural rate] is only a virtual discrepancy; as soon as the discrepancy becomes actual, the theory breaks down. (...) The case where expectation elasticity is equal to unity marks the dividing line between stability and instability.” (Hicks 1939, pp. 253-55).

${ }^{17}$ We may note, however, that the decline in the loan rate is not Wicksell's usual assumption of an increase in productivity.

${ }^{18}$ Hayek gives a similar account of the movement of relative prices during the cycle. As stressed by Hicks (1967), some delay (of consumption relative to wages, or in the wage rise) must be supposed for Hayek's story to make sense. As for Mises, see Bellofiore (1998, note 53), who supports Mises’ claim, i.e., a delay in wages.

${ }^{19}$ Insofar as they experience rising wages, they would rather increase their demand for consumption goods. ${ }^{20}$ Mises notes that a precise re-establishment of the old price ratio between goods of the first order and goods of higher orders is not possible. On one hand, the intervention of banks has brought about a redistribution of income and property. On the other hand, the automatic recovery of the loan market involves certain of the phenomena of a crisis such as the loss of some of the capital invested in the excessively lengthened roundabout processes of production. According to Mises, the remaining trace of all these disturbances will be a general 
increase of the objective exchange value of money (Mises [1924] 1981, p. 402).

${ }^{21}$ The case of an 'evenly rotating economy' is an imaginary construction because it describes an economy where any factor of change and the element of time are abstracted from. Mises defines it as follows:

"The evenly rotating economy is a fictitious system in which the market prices of all goods and services coincide with the final prices. (...).The system is in perpetual flux, but it remains always at the same spot. It revolves evenly round a fixed center, it rotates evenly. All factors (...) are constant. Therefore prices — commonly called static or equilibrium prices — remain constant too. $(\ldots)$

The essence of this imaginary construction is the elimination of the lapse of time and of the perpetual change in market phenomena. The notion of any change with regard to supply and demand is incompatible with this construction. Only such changes as do not affect the configuration of the price-determining factors can be considered in its frame." (von Mises [1949] 1996 : 261, emphasis added).

\section{REFERENCES}

Bellofiore, R. (1998) Between Wicksell and Hayek: Mises’ Theory of Money and Credit Revisited, The American Journal of Economics and Sociology 57(4), pp. 531-78.

Bien Greaves, B. \& McGee, R (Eds) (1993) Mises: An annoted Bibliography. A Comprehensive Listing of Books and Articles by and About Ludwig von Mises (Irvington-on-Hudson, NY: The Foundation for Economic Education).

Boianovsky, M. (1995) Wicksell's business cycle, The European Journal of the History of Economic Thought, 2(2), pp. 315-411.

Boianovsky, M. and Trautwein, H-M. (2001) An Early Manuscript by Knut Wicksell on the Bank Rate of Interest, History of Political Economy, 3(3), pp. 484-507. 
Chiodi, G. (1991) Wicksell's monetary theory (London: Palgrave Macmillan).

Davidson, D. (1909) Om stabiliseringen af penningens värde (Concerning Stabilization of the Value of Money), Ekonomisk Tidskrift, 11.

Del Vecchio, G. (1967) Le questioni Fondamentali Sul Valore Della Moneta, Richerche Sopra la Teoria Generale Della Moneta, Padova : Cedam.

Dupont, F. and Reus, E. (1996) Les économies monétaires séquentielles: Keynes et quelques autres. PhD dissertation. Faculty of economics of the University of Aix-Marseille (France).

Festré, A. (2002) Money, banking and dynamics: two Wicksellian routes from Mises to Hayek and Schumpeter, American Journal of Economics and Sociology 61(2), pp. 439-80.

Festré, A. (2003) Knowledge and individual behaviour in the Austrian tradition of business cycles: von Mises vs. Hayek, History of Economic Ideas 11(1), pp. 13-45.

Gårdlung, T. (1958) The life of Knut Wicksell (Stockholm: Almqvist \& Wiksel).

Gootzeit M. J. (1994) “Mises on cyclcical relative price changes during the cumulative process.” Economies et Société, Série OEconomia, Histoire de la pensée économique, 19 (4), pp. 93-109.

Hayek, F. A. (1934a) Carl Menger (1840-1921), Economica 1(November), pp.393-420. Reproduced in The Collected Works of F.A. Hayek (vol. IV.): The Fortunes of Liberalism (London: Routledge, 1992).

Hayek, F. A. (1931) Prices and Production (London: Routledge, 1935).

Hayek, F. A. (1956) In Honour of Professor Mises, in P. G. Klein (Ed), The Collected Works of F.A. Hayek (vol. IV.): The Fortunes of Liberalism (London: Routledge, 1992, pp. 130-36). 
Hayek, F.A. (1992) The Collected Works of F.A. Hayek, vol. IV: The Fortunes of Liberalism, edited by P. G. Klein (London: Routledge).

Hicks, J. R. (1939) Value and Capital: An Inquiry into some Fundamental Principles of Economic Theory (Oxford: Clarendon Press(.

Hicks, J. R. (1967) Critical Essays in Monetary Theory ( Oxford: Clarendon Press).

Kirzner, I. M. (1976) Ludwig von Mises and The Theory of Capital and Interest, in S. Littlechild (Ed), Austrian Economics, vol. II (Aldershot: Edward Elgar, 1990, pp. 51-65).

Lindahl, E. (1939) Studies in the theory of Money and Capital (New York: Rinehart).

Lindahl, E. (Ed) (1958) Selected Papers on Economic Theory (London: George Allen and Unwin).

Myrdal, G. (1939) Monetary Equilibrium (London: W. Hodge \& Co).

Sandelin Bo. (Ed) (2000) Knut Wicksell: Selected Papers in Economics, vol. II (London: Routledge).

Uhr, C. G. (1960) Economic Doctrines of Knut Wicksell (University of California Press).

von Mises, L. (1912) Theorie des Geldes und der Umlaufsmittel (Munich \& Leipzig: Duncker \& Humblot).

von Mises, L. (1924) The Theory of Money and Credit (Indianapolis: LibertyClassics, 1981).

von Mises, L. (1928) Monetary Stabilization and Cyclical Policy, German edn., Yena. Reproduced in P. Greaves (Ed)., On the Manipulation of Money and Credit (Free Mkt. Books, 1978). 
von Mises, L. (1933) Epistemological Problems of Economics, translation by G. Reisman ( Princeton: D. Van Nostrand, 1960).

von Mises, L. (1934) The Theory of Money and Credit, translation by H. E. Batson (London: Jonathan Cape Ltd).

von Mises, L. (1936) The ‘Austrian’ Theory of the Trade Cycle, in S. Littlechild (Ed), Austrian Economics, vol. II (Aldershot: Edward Elgar, 1990, pp. 291-96).

von Mises, L. (1949) Human Action: A Treatise on Economics. 4th edition by Bettina Bien Greaves ( Fox \& Wilkes Publishers, 1996).

von Mises, L. (1962) The Ultimate Foundations of Economic Science (Kansas City: Sheed Andrews \& Mc Meel, 2d edition, 1978).

Von Mises, L. (1981) The Theory of Money and Credit (Indianapolis: Liberty Classics).

Moss, L. S. (1976) The Monetary Economics of Ludwig von Mises, in L. Moss (ed), The Economics of Ludwig von Mises. Toward a Critical Reappraisal (Kansas City: Sheed \&Ward, pp. 13-49).

Patinkin, Don. (1965) Money, Interest and Prices. 2d edition ( New York : Harper and Row).

Rothbard, N. (1976) The Austrian Theory of Money, in E. G. Dolan (ed), The foundations of Modern Austrian Economics (Kansas City : Sheed \& Ward, inc. -Subsidiary of Universal Press Syndicate).

Seccareccia, M. (1990) The Two Faces of Neo-Wicksellianism during the 1930s': The Austrians and the Swedes, in D. Moggridge (Ed), Perspectives in the History of Economic Thought, vol. IV (Aldershot: Edward Elgar).

Shackle, G. L. S. (1967) The Years of High Theory (Cambridge: Cambridge University Press). 
Siven, C-H. (1997) Capital Theory and Equilibrium Method in Wicksell’s Cumulative Process, History of Political Economy 29(2), pp. 201-17.

Wicksell, K. (1893) Value, Capital and Rent, translation by S. H. Frohwein (London: Macmillan, 1954).

Wicksell, K.( 1907) Krisernas Gåta, translation by C. Uhr in 1953 as: Enigma of Business Cycles, in K. Wicksell, Interest and Prices (New York: M. Kelley Publishers, 1965, pp. 223-39).

Wicksell K. (1911) Lectures on Political Economy, vol. I (London : Routledge, $2^{\text {nd }}$ edn, 1934).

Wicksell, K. (1915) Note on trade cycles and crises, translation by Classen in 1935, in K. Wicksell, Lectures II: Money (New York : M. Kelley Publishers, 1967, pp. 209-14).

Wicksell, K. ([1929] 1935) Lectures on Political Economy, vol II , $3^{\text {rd }}$ edn. (New York: M. Kelley Publishers, 1967).

Wicksell, K. ([1898] 1936) Interest and Prices, translation by R. F. Kahn (New York: M. Kelley Publishers, 1965).

Wicksell K. (1909) The money rate of interest and commodity prices, originally published as Penningränta och varupris, Economik Tidskrift, in Bo Sandelin Ed), Knut Wicksell: Selected Essays in Economics (Routledge, 1999, pp. 40-45).

Wicksell, K. (1914) Rezension: L.v. Mises: Theorie des Geldes und der Umlaufsmittel, Zeitschrift für Volkswirtschaft, Socialpoltitik und Verwaltung 23, pp. 144-49. 
